and to glycogenolysis are characterized by a complex interplay of enzymes and hormones, which is vividly presented here. Among the subjects covered are the structure of glycogen, the properties and role of uridine diphosphate glucose and its related enzymes, of the branching and debranching enzymes, and of the phosphorylases. The glycogen-storage diseases are among the best examples of inborn errors of metabolism, in which most of the clinical and biochemical features can be explained on the basis of an enzyme defect. Six different forms of glycogen-storage disease have been described, each apparently resulting from lack of a different enzyme concerned in glycogenolysis. Biochemical studies on each type are presented here, and an account is given of a recently discovered related disorder associated with lack of the enzyme glycogen synthetase.

The standard of presentation is excellent throughout the book, and the discussions following each chapter are unusually interesting and free from trivialities. All workers concerned with carbohydrate metabolism and its disorders should find this Symposium of interest and value.

\section{Paediatric Aspects of Cerebral Palsy}

T. T. S. Ingram. Pp. xii +515 , illustrated. London E. \& S. Livingstone. 1964. 84s.

In the past ten years cerebral palsy has undergone more thorough reappraisal than any other familiar pædiatric condition. There are still many enigmas, especially in the field of causation. This book records the outcome of one such comprehensive and meticulous survey, this one from Edinburgh, where cerebral palsied children born between 1938 and 1953, and still living in the city in 1955 (208 individuals) are studied. Its content is far richer than this first beggarly description suggests. Over the kernel of a ten year local study is laid the true flesh of the book, a scholarly amalgam of experience with cerebral palsy, and a careful digest of all revelant world literature. It begins with a critique of classifications, and adopts as a basis the previously published Edinburgh system that differs from the Little Club (1959) grouping mainly by using the heading "Dyskinesia" to embrace some categories elsewhere separately distinguished. Under each heading, the subsequent plan of the book is to review the literature on causation, to study the ætiological background as disclosed by the Edinburgh series, citing illustrative case histories, and to provide a well-annotated account of clinical manifestations. Later chapters give detailed consideration to the influences of birth injury, of abnormalities of pregnancy, and of developmental malformation. The work is rounded off by an illuminating study of the fate of the patients ten years later.

Although the formidable array of detail and the large scope of the work suggest that it will be read in extenso mainly by those much occupied with the management of cerebral palsy (for whom it may become a sort of bible), there is much in it for all pædiatricians and neurologists, and for the general medical reader. Its well-informed guidance on classification, on the recognition of clinical syndromes and on prognosis has welcome practical implications, while the stimulus of Dr. Ingram's balanced and incisive criticism in many individual chapters enables even strangers to this field to obtain a firm grasp of an elusive subject, which is admittedly difficult to envisage as a whole.

\section{Some Aspects of Chronic Bronchitis}

Edited by F. A. H. Simmonds and L. B. Hunt. Pp. vii +187 illustrated. Edinburgh, London:

E. \& S. Livingstone. 1964. 12s. 6d.

This is a short collection of papers read at a $\vec{\Rightarrow}$ symposium held at the Royal Society of Medicine $\stackrel{?}{?}$ in 1963. It contains very little previously unpublished 0 material but is useful as a summary of recent work. The chapter by Gregg on the early recognition and management of chronic bronchitis is outstanding. Campbell discusses the treatment of advanced cases with his usual lucidity. There are several other good sections, including a very interesting one on epidemiology by Reed.

All in all, this is a useful little book by distinguished contributors. Its main value will be to the nonspecialist reader interested in current work on this common and intractable disease.

\section{Multiple Sclerosis-A Reappraisal}

D. MCAlpine, C. E. LUMSDEN and E. D. $\stackrel{\oplus}{A}$ ACHESON. Pp. $v+415$. Edinburgh and London: E. \& S. Livingstone. 1964. 50s.

This is a book primarily for the neurologist and the M.S. research worker. The first section, a lucid $\infty$ survey on epidemiology by Acheson, should be read by everyone interested in epidemiological conundra. 을 Summing up, Acheson states fairly that the evidence points to environmental rather than genetic influences $\rightarrow$ as casual. However, in the next section McAlpine re- $\frac{D}{O}$ ports a 7.4\% higher incidence for blood group "O" (series of 384) than in controls. As he says larget $\vec{P}$ groups are needed to validate this finding. It $\frac{8}{8} \mathscr{O}$ interesting that the predominance is similar to the or proven for duodenal ulcer, and suspected for mig. raine: blood groups deserve further study. A suc prising omission, for such an exhaustive study, is any mention of cultural, religious, social and family more as a possible cause of the peculiar distribution of M.S. Such influences which affect modes of emotional expression and repression are as worthy of attention as diet and climate.

Part II on "Clinical Studies" by the senior author contains the wisdom which can be got only by the singleminded devotion of a lifetime. When the riddle of Multiple Sclerosis is finally solved it will owe much to McAlpine's energy and infectious enthusiasm. The section draws attention to the benign form of the disease, and reviews the thorny matter of treatment, including A.C.T.H., and finally M.S. as a medico-social problem. The section would perhaps be more "1965" without detailed case histories.

Part III by Lumsden on "The Clinical Pathology of M.S." is crammed with information on the growing points of research. It surveys C.S.F. protein and $D$ its origin; enzymes, metabolites and amino acids, 을 lipids in demyclination, and finally the promising field of clinical immunology. This intriguing section $N$ is spoilt by the turgid style; it needs shorter sentences and strong editing.

\section{Disorders of Language}

Ciba Foundation Symposium. Edited by A. V. S. REUCK and M. O'CONNOR. Pp. xii +356 illustrated. London: J. \& A. Churchill. 1964. 50s.

This imaginative Ciba symposium assembled neurologists, psychiatrists and experts in linguistics and phonetics with representatives from philosophy, ${ }_{\mathbb{O}}$ experimental psychology and electrical engineering, 